Indexed by

\title{
Scopus
}

\section{INVESTIGATION OF LIGHTWEIGHT STRUCTURAL MATERIALS PRODUCED USING ALUMINUM SCRAPS WITH CEMENT MORTAR}

Crossref
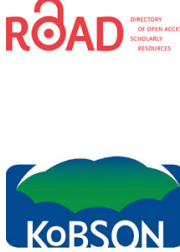

google

\section{Abdul_Qader Nihad Noori}

Mustansiriyah University,

Faculty of Engineering,

Civil Engineering Department,

Baghdad, Iraq

\section{Hesham A. Numan}

Mustansiriyah University,

Faculty of Engineering,

Civil Engineering Department,

Baghdad, Iraq

\author{
Jassim Muhsim Aliewi \\ Mustansiriyah University, \\ Faculty of Engineering, \\ Civil Engineering Department, \\ Baghdad, Iraq
}

\author{
Heba Kadhm Salman \\ Mustansiriyah University, \\ Faculty of Engineering, \\ Water Resources Engineering \\ Department, \\ Baghdad, Iraq
}

Key words: aluminum scraps, compressive strength, fine aggregate, lightweight, sustainable

Cite article:

Abdul_Qader, N. N, Jassim, M. A., Heba, K. S., \& Hesham, A. N. [2021]. Investigation of lightweight structural materials produced using aluminum scraps with cement mortar. Journal of Applied Engineering Science, 19(1), 252 - 257. DOI:10.5937/jaes0-27113

Online aceess of full paper is available at: www.engineeringscience.rs/browse-issues 


\title{
INVESTIGATION OF LIGHTWEIGHT STRUCTURAL MATERIALS PRODUCED USING ALUMINUM SCRAPS WITH CEMENT MORTAR
}

\author{
Abdul_Qader Nihad Noori'", Jassim Muhsim Aliewi', Heba Kadhm Salman², Hesham A. Numan ${ }^{1}$ \\ ${ }^{1}$ Mustansiriyah University, Faculty of Engineering, Civil Engineering Department, Baghdad, Iraq \\ ${ }^{2}$ Mustansiriyah University, Faculty of Engineering, Water Resources Engineering Department, \\ Baghdad, Iraq
}

A lot of environmental concerns are increasing day after day result in the raise of solid waste in large quantities in the world resulting from the demolition of buildings and various industrial and commercial activities. This research provides the possibility of reusing one of these wastes solid aluminum scrap (Als) by using it to produce a modified type of cement mortar. The research focuses on the mechanical behavior of the new cement mortar type obtained by adding aluminum scrap by different percentages $(1 \%, 2 \%, 3 \%, 4 \%$, and $5 \%)$ as a replacement ratio from the weight of sand mixed with Ordinary Portland Cement (OPC). The findings of this research indicated the possibility of using aluminum waste material in certain limits where the compressive strength significantly reduced by increasing the percentage of Als. The most interesting observation was to increase the volume of the mixture by increasing the ratio of Als. According to the results, it is possible to use this type of cement mortar to produce lightweight structural members such as slabs, bricks, etc. Finally, the general formulation was proposed based on the regression analysis and experimental measurements to give a capture of the compressive strength of mortar under any variables alter (age of specimen and/or quantity of aluminum replacement).

Key words: aluminum scraps, compressive strength, fine aggregate, lightweight, sustainable

\section{INTRODUCTION}

Per year, large amounts of industrial mineral scrap or merchandises generated worldwide. And in many countries, its adequate disposal is a grave problem. Heavy raw substances such as steel chips cast iron, steel, aluminum, from steel industries are the prime by-products of the metal industries [1]. Some researchers, such as [2, 3] founded that the use of alternative materials construction components could reduce from consumption of raw material. Aluminum is one of the world's most commonly used building materials, and huge quantities of waste are generated during production of aluminum [4].

The incorporation of waste in concrete production can solve the issues suitably posed by waste management. The building industry utilizes a substantial amount of natural substances; its reusing and upgrading capabilities are therefore important. For many years, some industrial materials utilized as cement or concrete ingredients. Additionally, some waste can also be reused and upgraded in concrete. However, the new substances formed must be useful as a construction material and have in particular the effectiveness features necessary to fulfill the requirements set out in its application. It should also be healthy in terms of safety and environment [5]. The consumption of aluminum recycling waste has been rising continuously worldwide [6].

Based on statistics from the World Bank for solid waste management, the cities in the world currently produce about 1.3 billion tons of solid waste annually, which will rise to 2.2 billion tons by 2025. [7]. Furthermore, the waste production rate expected to double over the following twenty years in lower-income nations [8]. The aluminum dross can be utilized as a partial substitution substance for cement in certain limits to gain economic and environmental advantages [9]. Aluminum dross and slag used as a filler material in the concrete product [10,11]. Additionally, the used aluminum dross worked to accelerate the strength development of concrete and positively affected the permeability of concrete [12]. The aluminum wastes serve as a retarder when poured the concrete under hot weather concreting [13]. As a result of adding aluminum waste in the concrete mixture, the initial and final setting times of concrete decreased. [14, 15]. The superior mechanical and durability of concrete properties could obtain when replaced $20 \%$ cement with aluminum dross [15]. Additionally, numerous nano-particles such as nano- $\mathrm{Al}_{2} \mathrm{O}_{3}$, nano- $\mathrm{SiO}_{2}$, nano-CuO, nano- $\mathrm{TiO}_{2}$, and nano-carbon tubes utilized to improve and accelerate the hydration [16 -20].

Incorporating granular iron slag and aluminum dross as a partial replacement material for Portland cement and natural sand, respectively, would produce eco-friendly concrete [21]. Both of microstructural and microstructural properties with employing aluminum slag and aluminum powder forming lightweight composites with densities below $2.15 \mathrm{~g} / \mathrm{cm}^{3}$ [22]. The values of electrical conductivity increased significantly at the low frequencies of the aluminum additions and silicon; especially at the high weight addition proportion $1.5 \%$ to produce smart mortar application [23]. The secondary aluminum dross within $10 \%$ in the Portland cement could be useful in the pro- 
duction of normal resistance concrete for the structural purpose by the construction industry [24].

\section{RESEARCH SIGNIFICANCE}

The development of industrial processes is increasing day after day, and this means a lot of industrial waste beside the material cost of getting rid of that waste. From here the idea of this research was presented by reusing metal waste (aluminum scrap) as a percentage ratio from the sand in the cement mortar to reach an acceptable compressive strength as regarding the structural side and reduces the cost of lightweight concrete manufacturing costs by seeking alternative materials. Additionally, the analysis of variance in statistical software was activated to present general formulation contains both the age of specimen and percentage of Als dosage with the compressive strength of the mortar proposed to become a guideline for future studies.

\section{EXPERIMENTAL WORK}

\section{Materials}

\section{Cement}

The main component in the mortar is OPC which obtained according to ASTM C150-07 Ordinary Portland cement (Type I) from Tasluja-Bazian manufactory. As depicted in Table 1 and Table 2, both the chemical and physical properties of cement utilized were harmonious with the Iraqi Standard Specification (IQS) No. 5/1984 [25].

\section{Fine aggregate (sand)}

In this work, all the admixture of mortars contains the sand that gained from AL-Ukhaidher with a maximum size of $4.75 \mathrm{~mm}$. The sand used was compatible with (IQS No. 45/1984) [26], as depicted in Table 3 and Fig. 1.

Table 1: Chemical components and main compounds of the cement utilized

\begin{tabular}{|c|c|c|}
\hline Compound Composition & $\begin{array}{c}\text { Chemical } \\
\text { Composition }\end{array}$ & $\%$ (weight) \\
\hline Lime & $\mathrm{CaO}$ & 63.26 \\
\hline Silic & $\mathrm{SiO}_{2}$ & 19.22 \\
\hline Alumina & $\mathrm{Al}_{2} \mathrm{O}_{3}$ & 4.51 \\
\hline Iron Oxide & $\mathrm{Fe}_{2} \mathrm{O}_{3}$ & 3.34 \\
\hline Magnesia & $\mathrm{MgO}$ & 2.62 \\
\hline Sulfate & $\mathrm{SO}_{3}$ & 2.03 \\
\hline Loss on ignition & L.O.I & 2.45 \\
\hline Insoluble residue & $\mathrm{I} . \mathrm{R}$ & 0.47 \\
\hline Lime saturation factor & L.S.F & 0.94 \\
\hline Tricalcium silicate & $\mathrm{C}_{3} \mathrm{~S}$ & 70.52 \\
\hline Dicalcium silicate & $\mathrm{C}_{2} \mathrm{~S}$ & 2.27 \\
\hline Tricalcium aluminates & $\mathrm{C}_{3} \mathrm{~A}$ & 6.31 \\
\hline Tricalcium alumina ferrite & $\mathrm{C}_{4} \mathrm{AF}$ & 10.15 \\
\hline
\end{tabular}

Table 2: Physical properties of the cement

\begin{tabular}{|c|c|}
\hline $\begin{array}{c}\text { Physical properties } \\
\mathrm{m}_{2} / \mathrm{kg}\end{array}$ & Test result \\
\hline $\begin{array}{c}\text { Specific surface area (Blaine Method), } \\
\text { Setting time (Vicat method) } \\
\text { Initial setting, hrs: min }\end{array}$ & 352 \\
\hline Final setting, hrs: min & $2: 35$ \\
\hline Compressive strength, MPa & $5: 20$ \\
\hline days & 20.8 \\
7 days & 26.0 \\
\hline Autoclave expansion \% & 0.24 \\
\hline
\end{tabular}

Table 3: Sieve analysis of fine aggregate

\begin{tabular}{|c|c|c|}
\hline Sieve Size $(\mathrm{mm})$ & $\begin{array}{c}\text { Cumulative } \\
\text { Passing \% }\end{array}$ & $\begin{array}{c}\text { Limit of Iraqi } \\
\text { specification } \\
\text { No. 45/1984 (zone 3) }\end{array}$ \\
\hline 10 & 100 & 100 \\
\hline 4.75 & 99.81 & $90-100$ \\
\hline 2.36 & 97.64 & $85-100$ \\
\hline 1.18 & 91.54 & $75-100$ \\
\hline 0.60 & 66.27 & 60.79 \\
\hline 0.30 & 15.07 & $12-40$ \\
\hline 0.150 & 2.21 & $0-10$ \\
\hline
\end{tabular}

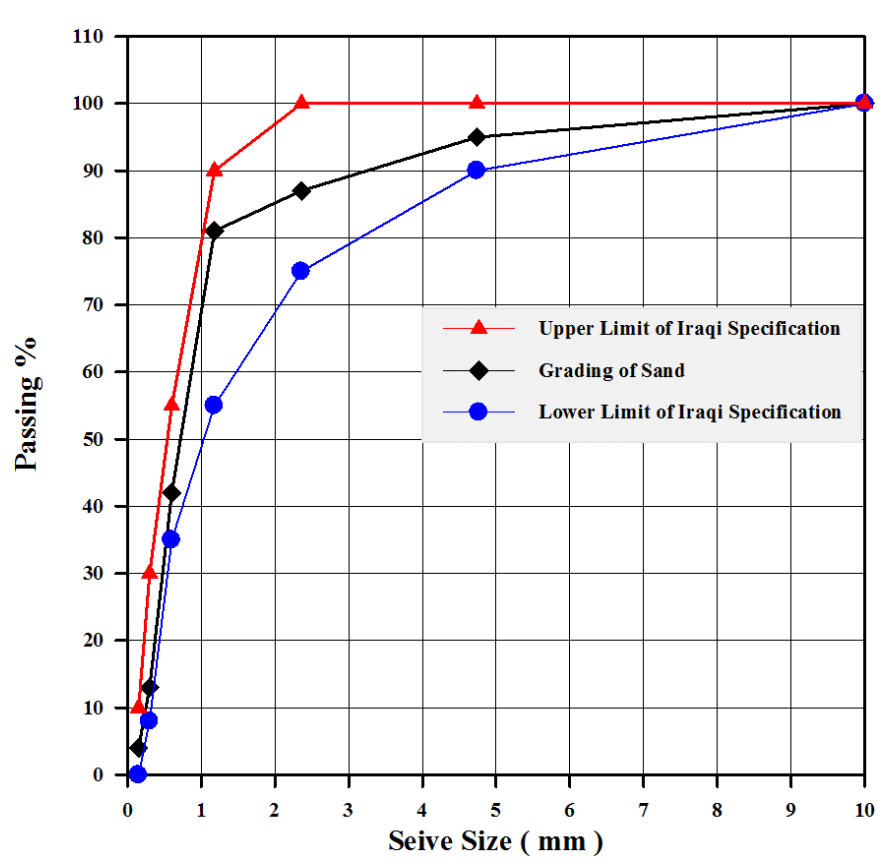

Figure 1: Sieve analysis for the sand used

\section{Mixing water}

In this research, the casting and curing process for all the samples done by using water from the ordinary tap without any additives and treatment. 


\section{Source of solid aluminum scrap (Als)}

Aluminum scrap particles (Als) assembled from factories producing aluminum sections, which used in the manufacture of many things (doors, windows, tables, and furniture, ..., etc.), widely distributed in the capital Baghdad. It cleaned of impurities and all foreign objects and then sieved on a sieve $4.75 \mathrm{~mm}$ and taken a pass from it for use in the production of modified cement mortar. The granules of Als used in this research are lightweight, and their irregular shape, as shown in Fig. 2.

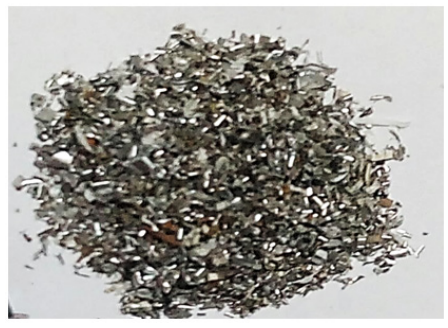

Figure 2: Solid aluminum scrap particles (Als)

\section{MOLDS}

The iron molds were used in the current work with a dimension $(50 \times 50 \times 50) \mathrm{mm}$. All these molds cleaned and oiled before the mortar poured into the molds.

\section{MIXES AND MIXING PROCEDURE}

All mixes made by weighted quantities (1: 2.73) (cement: sand) adopted in this study, Table 4 . The proportion of Water to Cement (W/C) was 0.485 also adopted and did not change for all mixes. The ratios of cement to sand and $\mathrm{W} / \mathrm{C}$ adopted in this study were within the range of the literature survey above. Additionally, the adopted proportion of W/C of 0.485 in this study to increase the workability as much as possible. The dry components (cement, sand, and the aluminum filling) mixed firstly in duration three minutes. Then, the water gradually added to the mix until getting a homogeneous mix. The mortar specimens were cast, compacted, and cured at the laboratory temperature within the range of (25-27). The Als content used as a replacement ratio from the sand weight.

\section{TESTING PROGRAM}

In this research, fifty-four cubic samples of $50 \mathrm{~mm}$ examined at age ( 3,7 , and 28 days); the compressive strength tests according to ASTM C109/C 109M, 2002 [27]. After mixing cement mortar with or without aluminum scraps, the fresh mortar was cast into cubic samples and cured for 3,7 , and 28 days in the curing water bath. Table 5 illustrates the compressive strength of cement mortar with a different proportion of Als.

\section{RESULTS AND DISCUSSIONS}

The data in Table 6 and (Fig. 3, Fig.4, Fig.5 and Fig.6) demonstrated that the addition (as replacement ratio from sand content) of 1 to $5 \%$ of solid aluminum scrap particles Als content to cement mortar leads to decrease the compressive strength by approximately $(27.29,35.48$, $40.69,60.30$ and 80.98$) \%$, respectively at the age of 3 days. The presence of aluminum scrap particles Als has a significant effect on compressive strength it is obvious from the experimental results that the reduction in the compressive strength with the rise in the proportion of Als content. At the age of 7 days, it found that the range of decreasing the compressive strength of mortar within the range of (25.82 to 79.47$) \%$ when increasing the Als content from (1 to 5 ) \%. Finally, at the age of 28 days, it found

Table 4: Proportion of mix design used

\begin{tabular}{|c|c|c|c|c|c|c|}
\hline \multicolumn{7}{|c|}{ Mix Design Label } \\
\hline Mix ID & Mix Design Label & Cement $\left(\mathrm{kg} / \mathrm{m}^{3}\right)$ & Sand $\left(\mathrm{kg} / \mathrm{m}^{3}\right)$ & w/c & $($ Als $)\left(\mathrm{kg} / \mathrm{m}^{3}\right)$ & (Als) \% By weight of sand \\
\hline 1 & Als0 & 662.24 & 1808.9 & 0.485 & 0 & 0 \\
\hline 2 & Als1 & 662.24 & 1790.81 & 0.485 & 18.09 & 1 \\
\hline 3 & Als2 & 662.24 & 1771.91 & 0.485 & 40.70 & 2 \\
\hline 4 & Als3 & 662.24 & 1753.82 & 0.485 & 61.05 & 3 \\
\hline 5 & Als4 & 662.24 & 1735.73 & 0.485 & 81.40 & 4 \\
\hline 6 & Als5 & 662.24 & 1717.64 & 0.485 & 101.75 & 5 \\
\hline
\end{tabular}

Table 5: The compressive strength results of cement mortar with different ratios of (Als) content

\begin{tabular}{|c|c|c|c|c|c|c|}
\hline \multicolumn{7}{|c|}{ Mix Design Label } \\
\hline $\begin{array}{c}\text { Age } \\
\text { (days) }\end{array}$ & $\begin{array}{c}\text { (Als0) } \\
\text { Reference } \\
\text { Specimen }\end{array}$ & $\begin{array}{c}\text { (Als1) content 1\% } \\
\text { by weight of sand }\end{array}$ & $\begin{array}{c}\text { (Als2) content 2\% } \\
\text { by weight of sand }\end{array}$ & $\begin{array}{c}\text { (Als3) content 3\% } \\
\text { by weight of sand }\end{array}$ & $\begin{array}{c}\text { (Als4) content } \\
\text { by by weight } \\
\text { of sand }\end{array}$ & $\begin{array}{c}\text { (Als5) content } \\
5 \% \text { by weight } \\
\text { of sand }\end{array}$ \\
\hline 3 & 22.24 & 16.17 & 14.35 & 13.19 & 8.83 & 4.23 \\
\hline 7 & 24.75 & 18.36 & 15.93 & 15.23 & 9.46 & 5.08 \\
\hline 28 & 33.82 & 20.18 & 17.64 & 16.98 & 12.47 & 7.12 \\
\hline
\end{tabular}


the decrease in the compressive strength of mortar within the range of $(40.33$ to 78.95$) \%$ when increased the Als content from (1 to 5$) \%$. From these outcomes, it found that the highest percentage of decreasing in the compressive strength of mortar took place at the age 3 days and with $5 \%$ content of Als, which was $80.98 \%$. These findings expected because of increasing the air gaps through addition to the Als in the mortar. The reason for increasing air gaps in admixture due to the chemical interaction took place between molecules of aluminum and calcium hydroxide that is in the peak level of interaction between these materials at the Als content $5 \%$ and the age of 3 days. The outcomes in this study demonstrated that the ratio of addition aluminum scrap particles to the cement mortar should be at the lowest level to obtain rational compressive strength in lightweight structural component could use in some construction applications.

Table 6: The average compressive strength outcomes of cement mortar with different ratios of (A/s)

\begin{tabular}{|c|c|c|c|c|}
\hline \multirow{2}{*}{$\begin{array}{c}\text { Specimen } \\
\text { No. }\end{array}$} & Als \% & \multicolumn{3}{|c|}{$\begin{array}{c}\text { The decrease in compressive } \\
\text { strength (\%) with respect to } \\
\text { reference specimen (Als0) }\end{array}$} \\
\cline { 2 - 5 } & & 3 days & 7 days & 28 days \\
\hline Als1 & 1 & 27.29 & 25.82 & 40.33 \\
\hline Als2 & 2 & 35.48 & 35.64 & 47.84 \\
\hline ALs3 & 3 & 40.69 & 38.46 & 49.79 \\
\hline ALs4 & 4 & 60.30 & 61.78 & 63.13 \\
\hline ALs5 & 5 & 80.98 & 79.47 & 78.95 \\
\hline
\end{tabular}

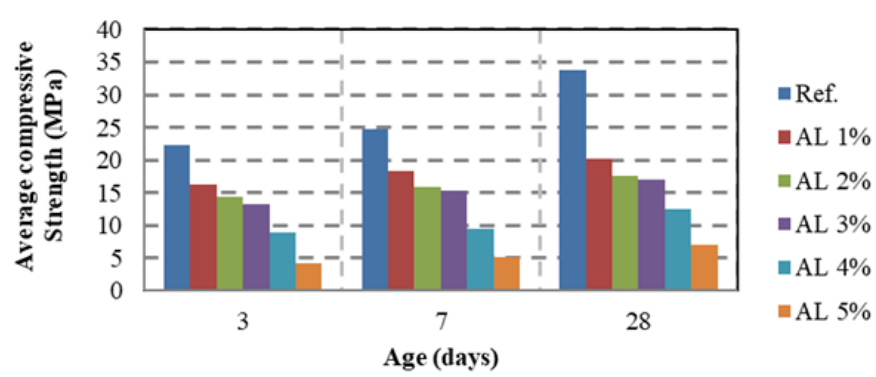

Figure 3: Compressive strength for cement mortar samples at 3, 7 and 28-day

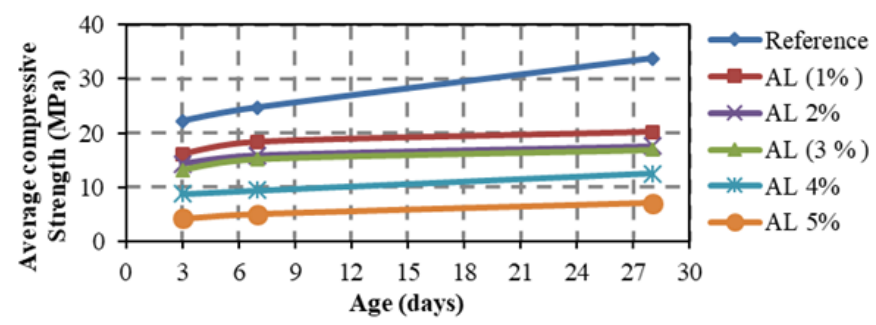

Figure 4: The compressive strength of samples with time

As shown in figure 6, it can see an increase in the sample size due to the reaction between the solid aluminum scrap particles (Als) and cement. The volume of samples increases by increasing the scrap ratio by approximately 10 to $40 \%$ when Als added with (1 and 5) \% respectively.
Due to the formation of hydrogen blebs in the mixture resulting from the chemical reaction between the aluminum particles with $\mathrm{Ca}(\mathrm{OH})_{2}$ from the hydration of the silicates. This reason explains why the size of the volume of the specimen increases.
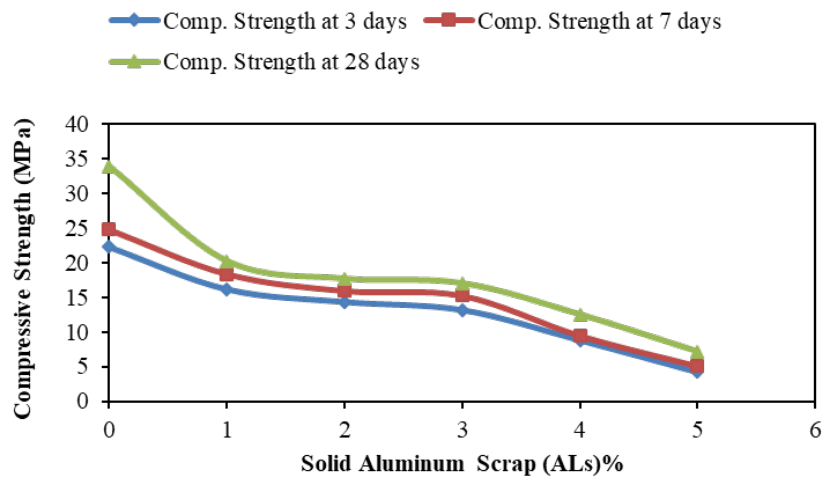

Figure 5: The decrease in ultimate compressive strengths with increasing of $(A / s) \%$

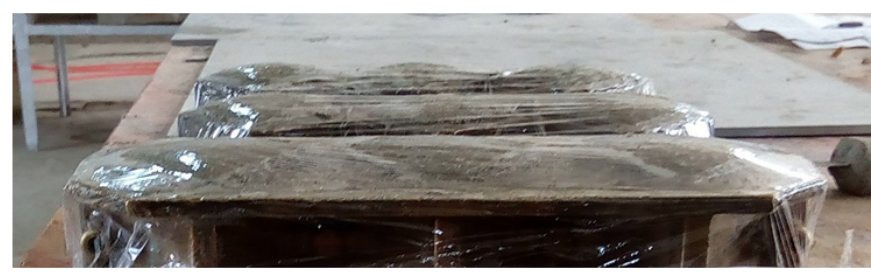

Figure 6: The increase in samples size due to increase in $(A / s) \%$ content

\section{STATISTICAL ANALYSIS OF THE EXPERIMENTAL RECORDS}

By activating the Fit Regression Model in MINITAB software, version 17 [28], with the stepwise regression procedure (step-by-step iterative analysis) to clarify the relationship between response value (compressive strength of cement mortar"Comp") with two predictor values (percentage replacement of aluminum instead of sand " $R$ " and the age of specimens" $A$ "). The relationship translated into regression formulations as shown in Eq. 1:

Comp. $=22.47+0,1812 \mathrm{~A}-377,4 \mathrm{R}$

From the above formulation, the $R$-square amounted a high value that is $90.35 \%$ with confidence level of $95 \%$. A closer look at this formulation, it found that both of the predictor variables $(\boldsymbol{R}$ and $\boldsymbol{A})$ were correlated linearly with the compressive strength of mortar. To more visibility about the interconnection of the response and predictor variables simultaneously for future studies; the matrix plot with smoother also activated, as illustrated in Fig.7. From this figure, it found that $\boldsymbol{R}$ negatively with Comp. and the general trend $\boldsymbol{A}$ with the Comp. is positive. These relationships in Fig.7 are considered logical due to increasing from a value of $R$ automatically worked to decrease the value of Comp. as a result of producing the hydrogen blebs within the mixture. On the other hand, the effects of hydration interaction reduce with the passage of time on samples, therefore, it explains to us 


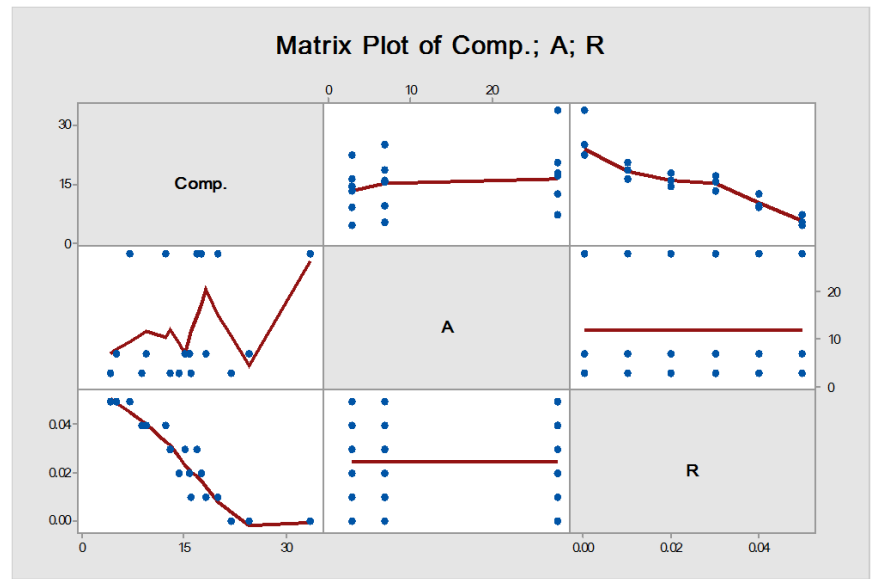

Figure 7: Matrix plot with smoother between response with predictor variables

why the inverse relationship happened between $A$ with the Comp. Additionally, the relationships in Fig.7 proved no clear relationship connects between $\boldsymbol{A}$ and $\boldsymbol{R}$.

\section{CONCLUSIONS}

1. The compressive strength value decreases with increasing solid aluminum scrap particles (Als) dosage, and this is related to the mixtures; comprising a high amount of (Als) have higher air content.

2. Replacement amounts of $1 \%, 2 \%$ and $3 \%$ of (ALs) can then be used to produce good quality mortar.

3. It noted that solid aluminum scrap particles (Als) content acts as an extending parameter, it could use in the manufacturing of blocks and pre-molded panels.

4. The modified cement mortar samples that contain (Als) had a water absorption much higher than conventional cement mortar.

5. To more visibility about the behavior of compressive strength of mortar under the combined effect of age and aluminum scrap ratio, the formulation listed by using regression analysis of variances. This formulation could consider the reference for future works.

\section{ACKNOWLEDGMENTS}

The authors would like to thank Mustansiriyah University (www.uomustansiriyah.edu.iq) Baghdad-Iraq for its support in the present work.

\section{REFERENCES}

1. Chowdhury, S., Roy, S., Maniar, A.T. and Suganya, O.(2014). Comparison of mechanical properties of mortar containing industrial by product. APCBEE procedia, 9, 317-322.

2. Yaseen, M.H., Abbu, M. and Numan, H.A.(2018). Influence of adding different amounts of polyethylene terephthalate on the mechanical properties of gypsum subjected to fire. International Journal of Civil Engineering and Technology, 9(10), 1721-1731.
3. Noori, A.N. and Numan, H.A.(2020). June. Behavior of sustainable reinforced concrete building containing waste plastic and fibers. In IOP Conference Series: Materials Science and Engineering, Vol. 870, 012094. doi:10.1088/1757-899X/870/1/012094.

4. Nesibe G. Ozerkan, Omar L. Maki, Momen W.Anayeh, Stian Tangen and Aboubakr M. Abdullah. (2014). The Effect of aluminum dross on mechanical and corrosion properties of concrete , International Journal of Innovative Research in Science, Engineering and Technology, 3(3), 9912-9922.

5. Elvis .M. Mbadike1 and N.N Osadere. (2014). Effect of incorporation of aluminum waste in concrete matrix using different mix ratio and water cement ratio, International Archive of Applied Sciences and Technology, 5(1), 47-54.

6. Bajare, D., Korjakins, A. and Kazjonovs, J. (2011). Application of aluminium dross and glass waste for production of expanded clay aggregate. Civil Engineering, 11, 27-31.

7. Hoornweg, D. and Bhada-Tata, P., (2012). What a waste: a global review of solid waste management, World Bank, Washington, DC,15, 116.

8. Oriyomi M. Okeyinka, David A. Oloke and Jamal M. Khatib. (2015). A review on recycled use of solid wastes in building materials, International Journal of Civil and Environmental Engineering, 9, 12.

9. Pereira, D.A., de Aguiar, B., Castro, F., Almeida, M.F. and Labrincha, J.A. (2000). Mechanical behaviour of portland cement mortars with incorporation of al-containing salt slags. Cement and Concrete Research, 30(7), 1131-1138.

10. Brough, M. (2002). Aluminium lightens the environmental load. Vision-The newsletter of the Foresight and Link Initiative, No(4).

11. Dai C.(2012).Development of aluminium drossbased material for engineering applications, M.Sc. Thesis, Material Science and Engineering, Worcester Polytechnic Institute.

12. Shinzato, M.C. and Hypolito, R. (2005). Solid waste from aluminum recycling process: characterization and reuse of its economically valuable constituents. Waste management, 25(1), 37-46.

13. Elinwa, A.U. and Mbadike, E. (2011). The use of aluminum waste for concrete production. Journal of Asian Architecture and Building Engineering, 10(1), 217-220.

14. Arimanwa, J.I., Onwuka, D.O., Arimanwa, M.C. and Onwuka, U.S. (2012). Prediction of the compressive strength of aluminum waste-cement concrete using Scheffe's theory. Journal of materials in civil engineering, 24(2), 177-183. 
15. Mailar, G., Sreedhara, B.M., Manu, D.S., Hiremath, P. and Jayakesh, K.(2016). Investigation of concrete produced using recycled aluminium dross for hot weather concreting conditions. Resource-Efficient Technologies, 2(2), 68-80.

16. Morsy, M.S., Alsayed, S.H. and Aqel, M., 2011. Hybrid effect of carbon nanotube and nano-clay on physico-mechanical properties of cement mortar. Construction and Building Materials, 25(1), 145-149.

17. Meng, T., Yu, Y., Qian, X., Zhan, S. and Qian, K. (2012). Effect of nano-TiO ${ }_{2}$ on the mechanical properties of cement mortar. Construction and Building Materials, 29, 241-245.

18. Rashad, A.M. (2013). Effects of $\mathrm{ZnO}_{2}, \mathrm{ZrO}_{2}, \mathrm{Cu}_{2} \mathrm{O}_{3}$, $\mathrm{CuO}, \mathrm{CaCO}_{3}, \mathrm{SF}, \mathrm{FA}$, cement and geothermal silica waste nanoparticles on properties of cementitious materials-A short guide for Civil Engineer. Construction and Building Materials, 48,1120-1133.

19. Li, W., Huang, Z., Cao, F., Sun, Z. and Shah, S.P. (2015). Effects of nano-silica and nano-limestone on flowability and mechanical properties of ultra-high-performance concrete matrix. Construction and Building Materials, 95,366-374.

20. Li, W., Huang, Z., Zu, T., Shi, C., Duan, W.H. and Shah, S.P. (2016). Influence of nanolimestone on the hydration, mechanical strength, and autogenous shrinkage of ultrahigh-performance concrete. Journal of Materials in Civil Engineering, 28(1), 04015068

21. Javali, S., Chandrashekar, A.R., Naganna, S.R., Manu, D.S., Hiremath, P., Preethi, H.G. and Kumar, N.V. (2017). Eco-concrete for sustainability: utilizing aluminium dross and iron slag as partial replacement materials. Clean Technologies and Environmental Policy, 19(9), 2291-2304.
22. Khater, H.M., (2019). Development and characterization of sustainable lightweight geopolymer composites. Ceramica, 65(373), 153-161.

23. Hamead, A.A.A., Ahmed, S.S., Azzat, S.R.A., Abed, M.S. and Hammod, G.K., (2020). Employing recycling materials for the fabrication of smart mortar. Materials Today: Proceedings, 20, 397-402.

24. Nduka, D.O., Ede, A.N., Olofinnade, O.M. and Ajao, A.M. (2020). Mechanical and Water Absorption Properties of Normal Strength Concrete (NSC) Containing Secondary Aluminum Dross (SAD). In International Journal of Engineering Research in Africa, Vol. 47, 1-13). Trans Tech Publications Ltd.

25. Iraqi Standard Specification (IQS), No.5, (1984). Portland Cement, Central Organization for Standardization \& Quality Control (COSQC), Baghdad, Iraq.

26. Iraqi Standard Specification (IQS), No.45, (1984). Aggregates from Natural Sources for Concrete and Construction, Central Organization for Standardization \& Quality Control (COSQC), Baghdad, Iraq.

27. ASTM C 109/C 109M-02, (2002). Standard Test Method for Compressive Strength of Hydraulic Cement Mortar, ASTM International.

28. Minitab 17 Statistical Software (2010). [Computer software]. State College, PA: Minitab, Inc. (www. minitab.com). 